\begin{tabular}{cc|c}
\hline Tar. Bil. Der. & Journal of Agricultural Sciences \\
& $\begin{array}{c}\text { Dergi web sayfası: } \\
\text { www.agri.ankara.edu.tr/dergi }\end{array}$ & Journal homepage: \\
& www.agri.ankara.edu.tr/journal
\end{tabular}

\title{
Determination of the Main Socio-Economic Factors of the Sustainable Production of Forage Crops: Research of Kayseri Province
}

\author{
Celal CEVHER ${ }^{\text {a }}$ \\ ${ }^{a}$ Fields Crop Central Research Institute, Şehit Cem Ersever St. Number: 9, Ankara, TURKEY
}

\author{
ARTICLE INFO \\ Research Article \\ Corresponding Author: Celal CEVHER, E-mail: celalcevher@hotmail.com, Tel: +90 (505) 8582275 \\ Received: 16 August 2018, Received in Revised Form: 25 September 2018, Accepted: 20 November 2018
}

\begin{abstract}
Today, about $21 \%$ of the Turkey's population lives engage plant production and animal husbandry; the most crucial aspect of livestock breeding is producing forage crops. Since 2000, growers in Turkey have been subsidized and encouraged to increase both their production and quality of forage crops. However, despite all this support and assistance, desired production levels have not yet been achieved. Therefore, it is equally crucial analyze the effects of factors other than the subsidies provided on forage crops production. This study aims to determine the socio-economic factors that affect sustainable forage crops production. The study was carried out in the province of Kayseri, specifically in 11 villages where both plant production and animal husbandry systems are common. The subjects of the study were selected through the Random Sampling Method and data was collected by surveying 310 forage crops growers. To identify dependency relationships between qualitative variables used mainly based on a statistical chi-square statistic. According to the analysis results, $35.5 \%$ of growers found forage crops production sustainable, whereas $64.5 \%$ of them thought that it was unsustainable. When both socio-economic variables and the answers to survey questions were taken into account, variables such as grower's age, education level, income level, land for fodder crops, livestock count, recent increase in livestock count, subsidies, and the conditions under which sustainability may be maintained were found to be related to forage crops production sustainability.
\end{abstract}

Keywords: Sustainability; Forage crops; Subsidies; Kayseri-Turkey

(C) Ankara Üniversitesi Ziraat Fakültesi

\section{Introduction}

Forage crops production is the backbone of livestock breeding. Forage crops both directly and indirectly improve the productivity of land use (Maç \& Yilmaz 2016). The fact that forage plants are rich in minerals and vitamins makes them enhance livestock productivity and produce quality foods from animals (Peters et al 2001). However, the amount of coarse fodder produced in Turkey is far outstripped by the feed demands of the existing livestock population
(Yolcu \& Tan 2008; Temel \& Şahin 2011). In Turkey, forage crops are grown in as much as $2.689,253$ hectares. Specifically, forage crops that are grown most often in Turkey are corn (976.698 ha), clover (676.172 ha) and common vetch (669.432 ha). When cultivated lands (15.464 ha) and fallow lands (4.286 ha) are combined, the proportion of the forage crop lands is $13.6 \%$ (BUGEM 2017). The first reason for this is that the coarse fodder yield in meadows and rangelands is low. The second reason is that the 
forage crops production is insufficient (Kusvuran et al 2011). Ecologically, Turkey has the necessary resources to meet the coarse fodder demand and feed its livestock population.

Turkey has a great potential for forage production, but this potential can be accomplished with active and more specific policy measures (Yilmaz \& Mac 2013). Therefore, there are plans to ameliorate Turkey's coarse fodder deficit. For this, efforts to improve meadows and rangelands have been intensified and forage crops growers are subsidized. Forage crop growers have been supported since 2000 to foster, promote, and keep track of livestock breeding in Turkey. One objective of the forage crops subsidy policies in place is sustainable forage crops production. It is well known that governmentprovided subsidies positively impact the amount of forage crops produced (Cevher et al 2012). However, the increase in the amount of production and productivity depend on both the subsidies and the forage crop growers' socio-economic features (Ward et al 2016). For instance, a study on developing livestock breeding found that socioeconomic features such as breeders' age, education level, non-agricultural activities, and production objectives affect livestock breeding (Demir \& Yavuz 2010). In another study (Karadavut et al 2011), proved that the growers' socio-economic features help their success in producing forage crops.

This study determines the socio-economic factors that affect growers' forage crops production and its sustainability. In addition, the socioeconomic variables that impact the sustainability of forage crops production and the subsidies given by the government have been studied. It is crucial to determine these variables to reinforce the government support for producing forage crops.

\section{Material and Methods}

\subsection{Data}

This study's subjects are registered growers who grow forage crops in Kayseri province, of whom there are 1.600. A random sampling method is used to select subjects among them (Yamane 2001) Equation 1 is used to determine the sample size.

$n=\frac{N p q z_{\alpha / 2}^{2}}{N d^{2}+p q z_{\alpha / 2}^{2}} \quad$ Equation 1

In this equation, $n$ is the sampling size, $p$ is the estimated percentage of the subjects saying that forage crops production is sustainable $(0.5), q$ is the estimated percentage of subjects saying that forage crops production is unsustainable $(0.5), N$ is the population size, $d$ is the sampling error $(0.05), \alpha$ is the first type error level (0.05), and $z$ is the standard normal distribution value (1.96). When all these values are placed into Equation 1, we have:

$n=\frac{1600(0.5)(0.5)(1.96)^{2}}{1600(0.05)^{2}+(0.5)(0.5)(1.96)^{2}}=309.78$

Based on this, the sample size should be at least 310 subjects. Accordingly, 310 registered growers were randomly selected for this study. In addition, 30 growers, roughly $10 \%$ of the sample size, were picked as substitute subjects, in case some primary ones chose not to answer the questionnaire or could not be reached. Thus, 310 growers were surveyed through face-to-face interviews.

\subsection{Analysis}

In this study, since the state of sustainability and socioeconomic variables are categorical, the relationship between variables was analyzed via chisquared test. $c$ was the number of columns and $r$ was the number of rows; the expected frequencies for each cell in a $c \times r$ frequency table were calculated as follows:

$E_{i j}=\frac{1}{n}\left(\sum_{k=1}^{r} O_{k j}\right)\left(\sum_{k=1}^{c} O_{i k}\right) \quad$ Equation 2

The test statistics showing the differences between the observed and expected frequencies are defined as follows:

$\sum_{j=1}^{c} \sum_{i=1}^{r}\left(\frac{\left(O_{i j}-E_{i j}\right)^{2}}{E_{i j}}\right) \quad$ Equation 3 
While the variables were independent, this statistic had a chi-squared distribution with an approximate degree of freedom of $(r-1)(c-1)$ (Ozkan et al 2016).

$$
\sum_{j=1}^{c} \sum_{i=1}^{r} \frac{\left(O_{i j}-E_{i j}\right)^{2}}{E_{i j}} \sim \chi_{(r-1)(c-1)}^{2} \quad \text { Equation } 4
$$

The Cramer $v$ correlation coefficient was calculated for the relationships that were found in the chi squared analysis.

$$
v=\sqrt{\frac{\chi^{2}}{n \times \min \{(r-1),(c-1)\}}} \quad \text { Equation 5 }
$$

This coefficient has a value between [0.1] and as it approaches 1, the correlation between the variables increases. As a measure of association, making the proviso that this indicator should not be considered as absolute support to guarantee or not the association between variables; however, it serves to clarify the type and magnitude of a possible relationship between the variables of interest. Additionally, a correlation graph is provided to make it easier to compare correlation coefficients and the data based on the analysis are evaluated by the significance level of $\mathrm{P}<0.05$.

In this study, the concept of sustainability in fodder crop production indicates whether the producer will continue to produce fodder crops when the supports (subsidizations) are removed.

\section{Results and Discussion}

\subsection{The demographic features}

The demographic features of subjects in this study are given in Table 1. Analyzing these features revealed that more than half of them were aged 46 or older. Another similar study found that the average age of the forage crop farmers was 46.2 years and they have an average education level of the farmers was nine years (Maç \& Yilmaz 2016). The percentage of growers who were elementary school graduates was $67.4 \%$, and $88.7 \%$ of growers live in rural areas. The percentage of growers who said that they had a low income was $10 \%$, while $17.1 \%$ said that they had a high income. The sustainability rate was 35.5 (Figure 1).

Table 1- Growers' demographic features $(n=310)$

\begin{tabular}{llrr}
\hline Variables & Value & $f$ & $\%$ \\
\hline \multirow{3}{*}{ Age } & $\leq 30$ & 30 & 9.7 \\
& $31-45$ & 117 & 37.7 \\
\multirow{4}{*}{ Education } & $\geq 46+$ & 163 & 52.6 \\
& Primary school & 209 & 67.4 \\
Living place & Middle school & 44 & 14.2 \\
& High school and higher & 57 & 18.4 \\
& Rural & 275 & 88.7 \\
Income level & Medium & 35 & 11.3 \\
& High & 31 & 10.0 \\
& How & 226 & 72.9 \\
& & 53 & 17.1 \\
\hline
\end{tabular}

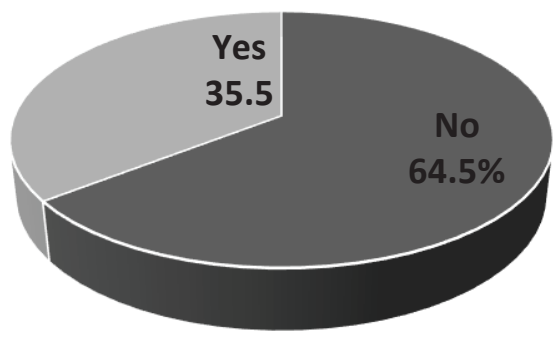

Figure 1- The distribution on the state of sustainability

\subsection{The chi square analysis results}

As shown in Table 2, the area in which growers reside and whether they had non-agricultural income had no significant effect on forage crop production sustainability $(\mathrm{P}>0.05)$. But, it is statistically significant for $\mathrm{P}<0.10$. In addition, growers' age, education level, income level, whether they owned forage crop land, livestock count, whether they received subsidies, the conditions under which sustainability was ensured and the effects of subsidies on livestock count had a significant relationship with sustainability $(\mathrm{P}<0.05)$.

Although (Cevher \& Tatlidil 2001; Çukur \& Işın 2008) found no significant relationship between 
Table 2- The Correlation of socio-economic variables with sustainability $(\mathrm{n}=\mathbf{3 1 0})$

\begin{tabular}{|c|c|c|c|c|c|c|c|c|}
\hline \multirow{3}{*}{ Variables } & \multicolumn{5}{|c|}{ Sustainable } & & \multirow{3}{*}{$\chi^{2}$} & \multirow{3}{*}{$P$} \\
\hline & & \multicolumn{2}{|c|}{ No } & \multicolumn{2}{|c|}{ Yes } & & & \\
\hline & Value & $f$ & $\%$ & $f$ & $\%$ & Total & & \\
\hline \multirow{3}{*}{ Age } & $\leq 30$ & 13 & 43.3 & 17 & 56.7 & 30 & \multirow{3}{*}{10.47} & \multirow{3}{*}{$0.005^{*}$} \\
\hline & $31-45$ & 86 & 73.5 & 31 & 26.5 & 117 & & \\
\hline & $\geq 46+$ & 101 & 62.0 & 62 & 38.0 & 163 & & \\
\hline \multirow{3}{*}{ Education } & Primary & 128 & 61.2 & 81 & 38.8 & 209 & \multirow{3}{*}{8.58} & \multirow{3}{*}{$0.014 * *$} \\
\hline & Middle & 37 & 84.1 & 7 & 15.9 & 44 & & \\
\hline & High & 35 & 61.4 & 22 & 38.6 & 57 & & \\
\hline \multirow{2}{*}{ Living place } & Rural & 183 & 66.5 & 92 & 33.5 & 275 & \multirow{2}{*}{3.11} & \multirow{2}{*}{$0.078 * * *$} \\
\hline & Urban & 18 & 51.4 & 17 & 48.6 & 35 & & \\
\hline \multirow{2}{*}{ Having off farm job } & No & 174 & 63.3 & 101 & 36.7 & 275 & \multirow{2}{*}{\multicolumn{2}{|c|}{$1.65 \quad 0.200$}} \\
\hline & Yes & 26 & 74.3 & 9 & 25.7 & 35 & & \\
\hline \multirow{3}{*}{ Income level } & Low & 27 & 87.1 & 4 & 12.9 & 31 & \multirow{3}{*}{30.64} & \multirow{3}{*}{$0.000 *$} \\
\hline & Medium & 156 & 69.0 & 70 & 31.0 & 226 & & \\
\hline & High & 18 & 34.0 & 35 & 66.0 & 53 & & \\
\hline \multirow{2}{*}{ Fodder crops area } & No & 36 & 90.0 & 4 & 10.0 & 40 & \multirow{2}{*}{16.58} & \multirow{2}{*}{$0.000^{*}$} \\
\hline & Yes & 152 & 56.3 & 118 & 43.7 & 270 & & \\
\hline \multirow{3}{*}{ Animal unit } & $1-15$ & 121 & 93.1 & 9 & 6.9 & 130 & \multirow{3}{*}{\multicolumn{2}{|c|}{$101.410 .000^{*}$}} \\
\hline & $16-30$ & 68 & 56.2 & 53 & 43.8 & 121 & & \\
\hline & 31 or more & 11 & 19.3 & 46 & 80.7 & 59 & & \\
\hline \multirow{2}{*}{$\begin{array}{l}\text { Taking forage crop } \\
\text { incentives }\end{array}$} & No & 154 & 93.3 & 11 & 6.7 & 165 & \multirow{2}{*}{127.96} & \multirow{2}{*}{$0.000^{*}$} \\
\hline & Yes & 46 & 31.7 & 99 & 68.3 & 145 & & \\
\hline \multirow{3}{*}{$\begin{array}{l}\text { Factors that ensure } \\
\text { sustainability }\end{array}$} & Feed support & 88 & 46.6 & 101 & 53.4 & 189 & \multirow{3}{*}{70.32} & \multirow{3}{*}{$0.000^{*}$} \\
\hline & Animal prices & 61 & 87.1 & 9 & 12.9 & 70 & & \\
\hline & Number of animals & 51 & 100.0 & 0 & 0.0 & 51 & & \\
\hline The effect of incentives to & No & 200 & 79.7 & 51 & 20.3 & 251 & 13240 & $0000 *$ \\
\hline increase animal numbers & Yes & 0 & 0.0 & 59 & 100.0 & 59 & 132.49 & 0.000 \\
\hline
\end{tabular}

Significance level: $0.01 *, 0.05 * *, 0.10^{* * *}$

sustainability and age, we found that the two were significantly related. The rate of growers, who were 30 years old or below and considered forage crops production sustainable was higher than that among growers in other age groups. Hence, sustainability is possible as it is easy to make young growers adopt innovations in agriculture. The percentage of growers whose education level was either primary or high and who considered forage crops production sustainable was greater than the percentage among middle school graduate growers. Several studies on Turkey's different crops found that education level and sustainability were related (Çukur \& Işın 2008; Kılıç \& Kıymaz 2014; Yildiz \& Boyacı
2017), indicating that growers with a higher level of education had a high level of sustainability. This could stem from the increased awareness of sustainability associated with an increased level of education.

Regarding income, the higher the income level, the higher the rate of growers who consider forage crops production sustainable; $66 \%$ of growers who have a high income maintain that forage crops production is sustainable, whereas only $12.9 \%$ of those with a low income consider it sustainable. Similarly (Topcu 2008), found that as the level of income increased, the willingness to benefit from agricultural subsidies also increased. Using logistic 
regression analysis (Kaya \& Atsan 2013) concluded that there was a significant relationship between income and the adoption of agricultural innovations. Out of the growers who owned forage crop lands, $68.3 \%$ stated that forage crops production was sustainable while only $6.7 \%$ of growers without any lands were positive about the sustainability of forage crops production. In a study conducted (Kaya \& Atsan 2013) concluded that there was a significant relationship between owning land area and subsidies. The subsidies for sustainable agriculture increased in proportion to land ownership.

In addition, the rate of sustainability visibly increased in accordance with the livestock count; $80.7 \%$ of growers who owned 31 or more livestock saw forage crops production as sustainable. This rate was only approximately $6.9 \%$ among growers with 1-15 livestock. In a study on this subject (Aksu \& Dellal 2016) concluded that increasing the number of the livestock positively influenced sustainability.

Whereas $68.3 \%$ of the growers who benefit from subsidies for producing forage crops saw it as sustainable, the rate of those without any subsidies who consider it sustainable was only $6.7 \%$. When the distribution between the suggestions for ensuring sustainability and sustainability itself were analyzed, the most valuable suggestion was to "increase the subsidies for forage crops"; $53.4 \%$ of the growers confirmed that forage crops production would be sustainable if subsidies increased. All growers who had increased their livestock count thanks to subsidies found forage crops production sustainable.

Figure 2 shows the Cramer $v$ correlation coefficients between the significant variables and the state of sustainability; the thicker the line, the more significant the correlation. The increase in the livestock count was the most significant variable $(v=0.654)$, followed by the variable for whether the grower received any subsidies $(v=0.642)$. The third most significant variable that had an effect on sustainability was the livestock count $(v=0.574)$.

\subsection{Discussion}

To benefit from support for feed plants in the study area, manufacturers with sensible fields should be provided with convenience. Because $41 \%$ of the tapestries in the research area are sensible territories

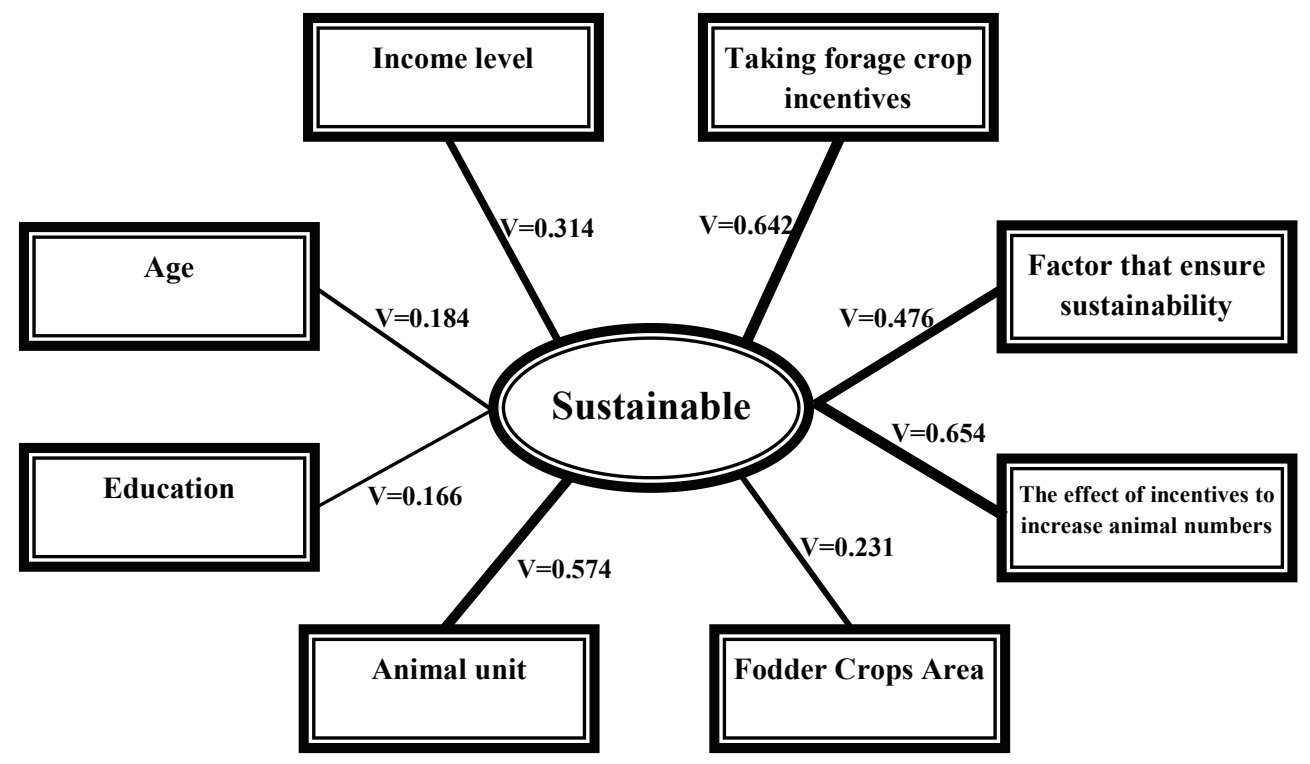

Figure 2- Correlation graph (the thicker the line is, the more significant the correlation is) 
and producers can't benefit from the incentive. This is an obstacle to increased production. Manufacturers who have leased treasury and neighboring land have stated that they do not benefit from support. This is an obstacle to the increase in production of feed plants. If this situation is done in favor of the producer, it will contribute to the increase of production. In addition to support for increased production of feed crops, agricultural publication studies and increased need for coarse feeds have also been effective. In this context, emphasis on agricultural publishing studies will increase production. $50 \%$ of perennial feed plants should be given in breeding. This will lead to an increase in production. Feed plant supports have put production of feed plants in an advantageous position in production pattern (according to other products). This has contributed to the increase in production of feed plants. Maintaining this support will contribute to the production of feed plants, the improvement of soil structure and the increase in the profit of operation in operation.

\section{Conclusions}

This study reveals that forage crops production closely depends on growers' income level, whether they own forage crop lands, livestock count, whether they receive subsidies, the conditions under which sustainability is maintained, and the effects of subsidies on livestock count. In particular, livestock count significantly correlates with sustainability. This study indicates that the increase in livestock count due to subsidies given is the most important factor for ensuring sustainability. The rate of growers who have increased their livestock count thanks to subsidies is $19 \%$ (59 out of 310 growers). Moreover, all these growers find forage crops production sustainable. Thus, forage crops production subsidies are insufficient and should be increased. In addition, stockbreeding should be turned into a more lucrative line of business by stabilizing the prices of animalbased products in commodity markets, which would encourage increased livestock counts. It is necessary to boost breeders' purchasing power. Apart from enhancing the livestock, receiving subsidies is confirmed as directly impacting sustainability. One reason for this could be that forage crop lands and the amount of production soar after subsidies are reimbursed. Another reason could be that subsidies greatly encourage forage crops production compared to regular crop production. It is seen that growers' financial situations really matter with regard to sustainability. This paper found that the rate of sustainability among growers with a larger income was high, which was why extending additional subsidies and supplying equipment and labor support to the growers with low income in particular could play an important role in ensuring sustainability. Since whether a person owns forage crop lands affects the sustainable production of such crops, a hike in the amount of forage crops would mean a hike in the sustainability. When growers were interviewed on the conditions under which forage crops production could be sustainable, it was concluded that increasing subsidies and livestock prices would encourage sustainability. In addition, the following course of action should be taken to reinforce coarse fodder production in Turkey: it is particularly necessary to enhance the quality of fodder, add forage crops to growers' growing cycle, make use of publications on forage crops, and collaborate with universities. Promotion of young population through support (subsidizations) and training activities, the effectiveness of producer organizations to benefit from support (subsidizations) will contribute to sustainable forage production.

\section{References}

Aksu N \& Dellal I (2016). An evaluation for Afyonkarahisar province on relationship of feed crops subsidy with bovine livestock activities. Yuzuncu Yil University Journal of Agricultural Sciences 26(1): 52-60

BUGEM (2017). Activities of BUGEM general directorate of vegetative production. Retrieved in March, 20, 2017 from http://www.tarim.gov.tr

Cevher C \& Tatlıdil H (2001). Evaluation of publication activities in the development of roughage feeds. 4. Congress of Field Crops, 17-21 September, Tekirdağ, pp. 109-115

Cevher C, Köksal Ö \& Ceylan I C (2012). Effects of agricultural support on fodder production and the 
sustainability: The case of Kayseri province. X. National Agricultural Economics Congress Books, 5-7 September, Samsun, pp. 37-43

Çukur T \& Işın F (2008). Industrial tomato producers' practices on sustainable agriculture in Torbali district of İzmir. Journal of Agricultural Faculty of Ege University 45(1): 27-36

Demir N \& Yavuz F (2010). A regional comparative analysis of farmers' approaches to livestock support policies. Journal of Agricultural Faculty of Atatürk University 41(2): 113-121

Karadavut U, Genc A, Palta C, Carkacı D A \& Kokten K (2011). Socioeconomic structure of meadow plants producers in Konya province and determination of success on affecting factors. Science Journal of Bingol University 1(2): 38-50

Kaya T E \& Atsan T (2013). Factors affecting rural women's adoption of organic agriculture (TRA1 of Sample). Atatürk University Journal of the Agricultural Faculty 44(1): 43-49

Kılıç Y \& Kıymaz T (2014). The relationship between education and labor productivity in agriculture: regional differences. Turkish Journal of Agricultural Economics 20(1): 53-64

Kusvuran A, Nazli R İ \& Tansi V (2011). Current situation of meadow-rangelands, animal existence and cultivation for forage crops in turkey and east black sea region. Journal of Agricultural Faculty of Gaziosmanpasa University 28(2): 21-32

Maç H \& Yilmaz H (2016). Analysis of factors related with farmers' benefiting from forage crops production support: Evidence from a survey for the Central Anatolia Region of Turkey. Revista De La Facultad De Agronomia De La Universidad Del Zulia (LUZ) 33: 232-254

Ozkan U, Gamgam H \& Altunkaynak B (2016). SPSS Uygulamalı Temel İstatistik Yöntemler. Seçkin Yayınevi, $1^{\text {th }} .710$, Ankara
Peters M, Horne P, Schmidt A, Holmann F, Kerridge P C, Tarawali S A, Schultze-Kraft R, Lascano C E, Argel P, Stür W, Fujisaka S, Müller-Sämann K \& Wortmann $\mathrm{C}$ (2001). The role of forages in reducing poverty and degradation of natural resources in tropical production systems. Agricultural Research \& Extension Network, pp. 117: 1-12

Temel S \& Şahin K (2011). The current situation, problems and suggestions for forage crops in Iğdır province. Yuzuncu Yil University Journal of Agricultural Sciences 21(1): 64-72

Topcu Y (2008). Effective factors' analysis on willingness to utilize from farmers' agricultural support policies: The case study of Erzurum province. Akdeniz University Journal of Agricultural Sciences 21(2): 205-212

Yamane T (2001). Basic sampling methods, translation. Translated by Esin A, Aydin C, Bakir M.A, Gurbuzsel E. Literature Publications 53, $1^{\text {th }}$ Ed, Textbook 580, Turkey

Yildiz O \& Boyac1 M (2017). Sustainability of farmers' practices according to extensionits: case of Aegean region. Turkish Journal of Agricultural Economics 23(2): 271-280

Yilmaz H \& Maç H (2013). Evaluation of the effects on production of forage crops production support policies in Turkey. Proceedings of the $1^{\text {st }}$ International Conference on New Directions in Business, Management, Finance and Economics (ICNDBM 2013), 12-14 September, Famagusta, Northern Cyprus, pp. 158

Yolcu H \& Tan M (2008). General view to Turkey forage crops cultivation. Journal of Agricultural Sciences 14(3): 303-312

Ward P S, Bell A R, Parkhurst G M, Droppelmann K \& Mapemba L (2016). Agriculture Ecosystems and Environment 222: 67-79 